UCRL-ID-130568

\title{
Test of a Chemical Dispersant for the Control of Scale Formation at Treatment Facility D
}

\author{
P W Krauter \\ J E Harrar \\ S.P. Orloff
}

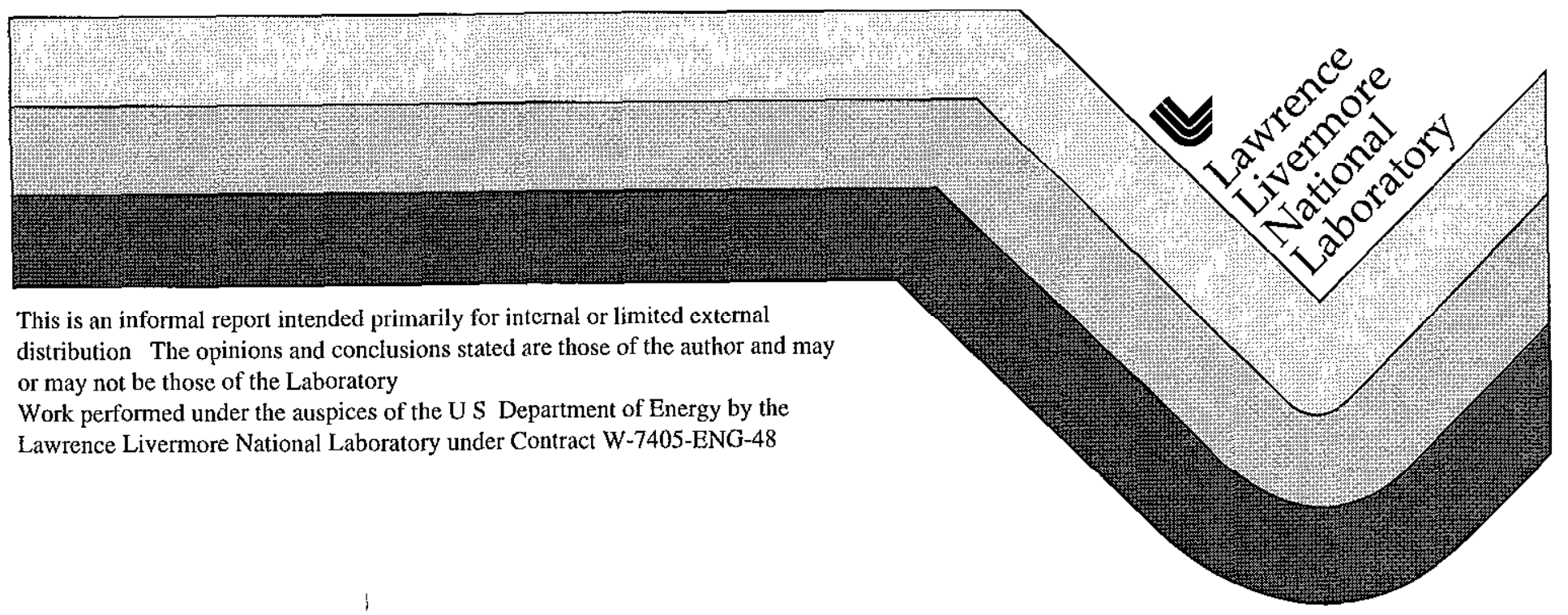




\section{DISCLAIMER}

This document was prepared as an account of work sponsored by an agency of the United States Government. Neither the United States Government nor the University of California nor any of their employees, makes any warranty, express or implied, or assumes any legal liability or responsibility for the accuracy, completeness, or usefulness of any information, apparatus, product, or process disclosed, or represents that its use would not infringe privately owned rights. Reference herein to any specific commercial product, process, or service by trade name, trademark, manufacturer, or otherwise, does not necessarily constitute or imply its endorsement, recommendation, or favoring by the United States Government or the University of California. The views and opinions of authors expressed herein do not necessarily state or reflect those of the United States Government or the University of California, and shall not be used for advertising or product endorsement purposes.

This report has been reproduced directly from the best available copy.

Available to DOE and DOE contractors from the Office of Scientific and Technical Information

P.O. Box 62, Oak Ridge, TN 37831

Prices available from (615) 576-8401, FTS 626-8401

Available to the public from the

National Technical Information Service

U.S. Department of Commerce

5285 Port Royal Rd.,

Springfield, VA 22161 


\title{
Test of a Chemical Dispersant for the Control of Scale Formation at Treatment Facility D
}

\author{
P W. Krauter, J. E. Harrar and S. P. Orloff \\ Environmental Protection Department \\ Lawrence Livermore National Laboratory \\ University of California \\ Livermore, California 94551
}

\section{Introduction}

At the Lawrence Livermore National Laboratory (LLNL), ground water is being treated to remove contaminants such as volatile organic compounds and chromium by several types of processes. At Treatment Facility D, remediation of volatile organics is accomplished by sparging the water with air, and the chromium is removed by an ion-exchange process. The air stripping has the effect of raising the $\mathrm{pH}$ of the water from $\sim 7$ to $\sim 8$, probably as result of removing carbon dioxide from the water. In the absence of further water treatment, calcium carbonate $\left(\mathrm{CaCO}_{3}\right)$, or calcite, deposits on the downstream equipment as a scale, which causes operational problems. At present, this scale deposition is being controlled by the addition of a polyphosphate formulation (JP-7, Jaeger Products, Inc, Houston, TX), but the use of this chemical is not completely satisfactory because of stringent phosphate discharge limits for the treated water A more benign method of scale control would be highly desirable. Therefore, we evaluated an organic chemical dispersant as a possible alternative.

\section{Equipment and Experimental Methods}

The progress of each test was monitored by means of several techniques First, the general behavior of the air-stripping process, as monitored by pressure in the flow system, was measured. Second, weighed test coupons to measure the accumulation of scale were placed in the system at various points. These coupons consisted of $10-\mathrm{cm}$ circular or square sections of stainless-steel screen Third, the apparent corrosion rates of mild steel at two points in the system were measured by means of the Linear Polarization Resistance (LPR) technique (Mansfeld, 1975). In brief, this technique exploits the fact that corrosion is an electrochemical process. The LPR instrument applies a voltage to a specimen of metal, and an electrolysis current is measured, which is converted to an equivalent, long-term corrosion rate. Because the formation of an impervious scale on the specimens decreases the corrosion rate, the LPR technique is an indirect indicator of the rate of scale formation In addition, the important water 
chemistry parameters were measured periodically at points in the system during the tests.

\section{TFD system description}

Figure 1 is a schematic diagram of the overall system at Treatment Facility D (see the Operations and Maintenance Manual, Groundwater Treatment Facility "D", Building 472 and Adjacent Equipment, Rev. 0, Lawrence Livermore National Laboratory, November, 1995, for additional details and the operating characteristics of this facility). In this facility, water from several wells is pumped into a 6 " influent line which flows into the treatment process The treatment process is operated on a $24 \mathrm{~h} / \mathrm{d}, 7 \mathrm{~d} / \mathrm{wk}$ basis. The scaling tests reported here were conducted while the facility was operated in this manner, with the specimens and coupons remaining in place throughout the test. The LPR and $\mathrm{pH}$ measurements were carried out at $24 \mathrm{~h}$ intervals.

\section{Belsperse 161}

The additive tested was Belsperse 161, supplied by the FMC Corp. (Philadelphia, PA) It is an acrylic acid polymer with sodium phosphinate (CAS No 71050-92-9). The manufacturer-suggested dosage for TFD water was $1.5 \mathrm{mg} / \mathrm{L}$ This dosage was derived from empirical knowledge, not stoichiometry, as in the case of JP-7. For injection of the diluted (1:20) Belsperse 161 into the process water, the injection rate was $67 \mathrm{~mL} / \mathrm{min}$ based on a $60 \mathrm{gpm} \pm 0.2 \mathrm{gpm}$ water flow rate. As shown in Figure 1, Belsperse 161 was injected in to the main water-supply line before the Cuno particulate filters and before the two stages of air stripping.

\section{Water Chemistry}

The major water quality parameters (total hardness, total alkalinity, calcium, and total dissolved solids) were measured at the influent and after the air-strippers prior to the injection of Belspere 161 and again after 2 weeks of Belspere 161 injection. The $\mathrm{pH}$ was measured using an Beckman $210 \mathrm{pH}$ meter and a No. 39841 electrode Samples for these tests were taken at the locations shown in Figure 1 Samples of the ground water were also analyzed for general water quality chemistry by a certified contract laboratory, California Laboratory Services, Inc (Rancho Cordova, CA)

\section{Coupons}

Coupons for the primary measurement of scale accumulation consisted of 10-cm circles or squares cut from Type 304 or 316 steel screen These were cleaned with acetone, weighed to the nearest $0.1 \mathrm{mg}$, and suspended with stainless steel wires in the air-stripper chambers. 


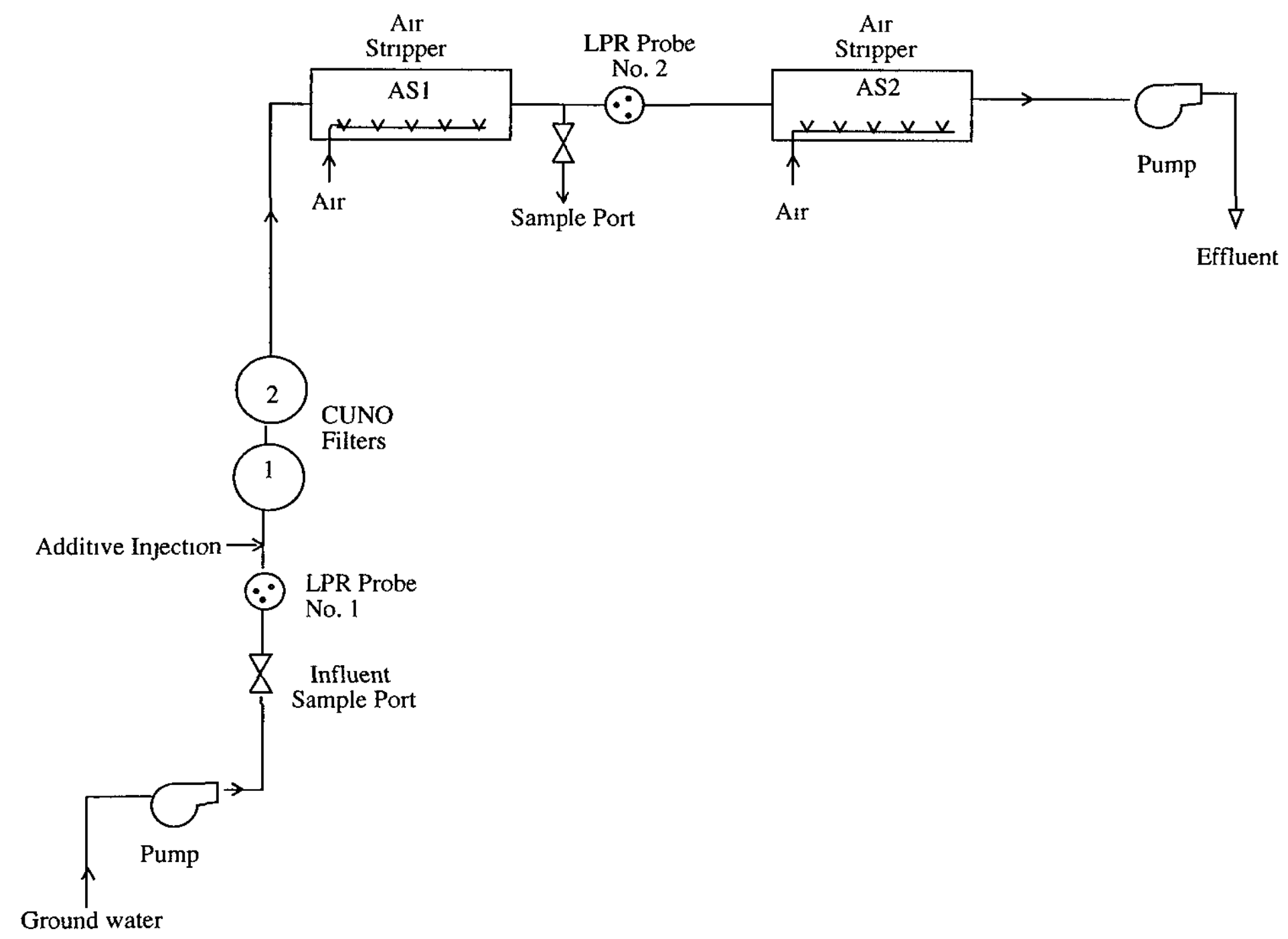

Figure 1. Simplified schematic diagram of flow system at Treatment Facility D 


\section{Linear Polarization Resistance Measurements}

The LPR measurements were performed with a Cortest (Willoughby, OH) Model IN-7500 meter, and type PR-515GS, stainless-steel probes fitted with Type 1018 mild steel electrodes. The instrument was set up to measure the corrosion rates anodically on a 5 -min time cycle. The instrument was calibrated before every series of measurements using the Cortest $10 \mathrm{mpy}$ (mils/year, 0 001-in /year) "meter prover" resistor, which was supplied with the instrument The steel electrodes were cleaned with acetone and kept in a desiccator before installation of the probes in the treatment system. As shown in Figure 1, LPR probes were installed in two locations in the treatment system

\section{Air Diffuser Pressure Measurement}

An operational characteristic of the treatment facility equipment that became a good indicator of the extent of scaling was the back pressure on the diffusers in the air stripper tanks These diffusers consist of sections of pipe that are drilled with multiple 3/8-in holes through which the air flows into the water as it is pumped through the tanks. The formation of scale in and around these holes restricts the openings and creates increasing back pressures that were indicated on gauges and recorded during the treatment runs. 


\section{Results and Discussion}

\section{General Water Chemistry}

A summary of the major parameters of the water that was used in this study is presented in Table 1 . The following elements were also measured, but were not detected at or above the reporting limits. $\mathrm{Al}, \mathrm{Cu}, \mathrm{Fe}, \mathrm{Mg}, \mathrm{Ni}, \mathrm{P}$, and $\mathrm{Zn}$

\footnotetext{
Table 1. Major water quality characteristics of the influent water processed in the scaling tests
}

Analyte

$\mathrm{pH}$ (units)

Specific Conductance $(\mu S)$

Total Dissolved Solids

Hardness, as $\mathrm{CaCO}_{3}$

Total Alkalinity, as $\mathrm{CaCO}_{3}$

Bicarbonate Alkalinity, as $\mathrm{CaCO}_{3}$

Sodium

Potassium

Calcium

Magnesium

Chloride

Sulfate

Fluoride

Nitrate, as $\mathrm{NO}_{3}^{-}$

Nitrite, as $\mathrm{NO}_{2}{ }^{-}$

Temperature $\left({ }^{\circ} \mathrm{C}\right)$

Concentration, mg/L

\subsection{3}

1200

770

340

230

230

160

\section{8}

78

35

210

83

066

22

$<25$

An effect of air stripping is to raise the $\mathrm{pH}$ of the water by 1 to $1.5 \mathrm{pH}$ units, presumably because dissolved carbon dioxide is removed Throughout the dispersant test period, the influent water maintained a $\mathrm{pH}$ between 7.09716 ; the water after the primary air stripper ranged from 8.03-8 11; and the water after the secondary air stripper was between $841-8.48$ at $20^{\circ} \mathrm{C}$ Except for $\mathrm{pH}$, no significant differences were found in the water chemistry values of the treated ground water compared to the untreated water (Krauter et al, 1996)

The Langelier Saturation Index (LSI) is an estimation of a solution's tendency to dissolve or deposit calcium carbonate. It is also often used as an 
indicator of the corrosivity of water. The index is not related directly to corrosion, but is related to the deposition of a calcium carbonate film or scale that can insulate surfaces from contact with water The LSI is calculated from the total dissolved solids, calcium concentration, total alkalinity, $\mathrm{pH}$, and solution temperature. The Ryznar Saturation Index (RSI) is an alternative index to LSI The difference between these indices is that Langelier derived his index from an analysis of chemical equilibrium, whereas Ryznar correlated the computed values of the index to field observations (Tchobanoglous and Schroeder, 1987) These water indices were calculated for the TFD water, before and after air stripping, using WindowChem ${ }^{\mathrm{TM}}$ Water Indices software. In Table 2, the LSI calculated for the influent water shows that it is slightly corrosive, and after the air-stripping process the effluent water is scale-forming.

Table 2 Calculated Langelier and Ryznar Saturation Indices of the influent and effluent water

\begin{tabular}{lllrl}
\hline Influent water & $\mathrm{pH} 713$ & LSI & -0.09 & $\begin{array}{l}\text { slightly corrosive } \\
\text { corrosive }\end{array}$ \\
& & RSI & 731 & \\
Effluent water & $\mathrm{pH} 8.43$ & LSI & 1.23 & scale-forming \\
& & RSI & 5.99 & scale-forming \\
\hline
\end{tabular}

\section{Facility Operational Characteristics}

A very good indicator of the extent of scaling was the back pressure on the diffusers in the air stripper tanks Figure 2 compares the air-stripper diffuser back pressures in water treated with JP-7 and Belsperse 161 With Belsperse 161 treated water, there was essentially no change in the back pressure during this test With JP-7 treatment, the pressure started to increase after about 32-day's running. After $71 \mathrm{~d}$ of operation the air stripper pressure was up to 49 inches of water Over the $71 \mathrm{~d}$ of operation, the back pressure increased $023^{\prime \prime}$ water/d in air stripper 1 (AS1), and $0.27^{\prime \prime}$ water/d in air stripper 2 (AS2) The facility, which processes $60.7 \mathrm{gpm}, 24 \mathrm{~h} / \mathrm{d}$, was stopped to remove and clean the diffusers when the pressure approached 50 inches of water.

A batch treatment process was formerly used at TFD, and this was conducive to forming scale (Krauter et al., 1996). The current procedure of continuous flow decreases the scale forming rate, possibly by keeping the calcite crystals suspended However, even with the continuous process, the system using JP-7 required clean out after 71 days (see Fig. 2). 

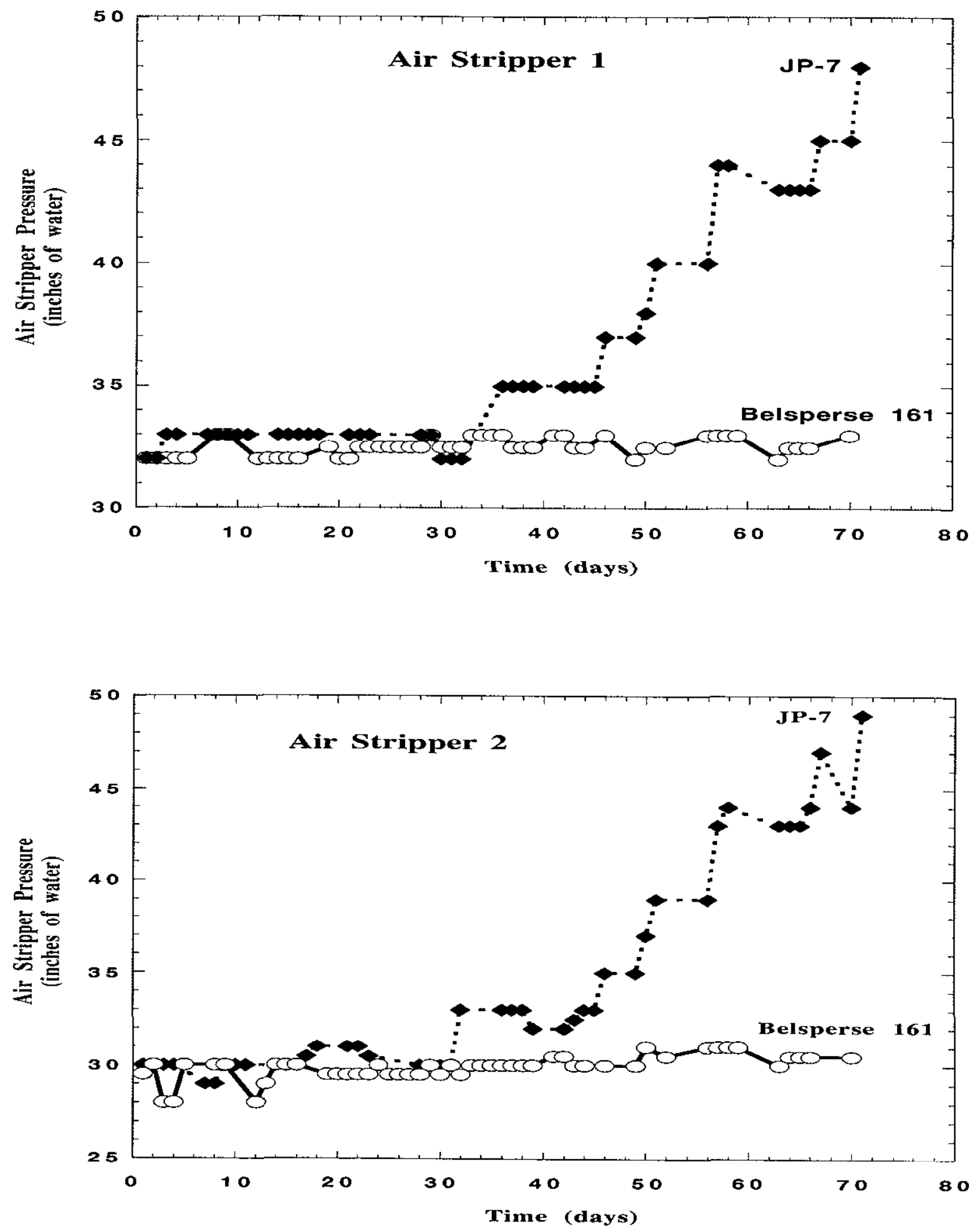

Figure 2. Daily pressure measurements in air strippers 1 and 2 with the phosphate additive (JP-7) and the phosphinocarboxylic polymer (Belsperse 161). 
Results of Coupon Weight-loss (or gain) Tests

Two coupons made from stainless-steel screen were suspended in each of the two air stripper tanks to measure the accumulation of scale gravimetrically; Table 3 presents the results of this experiment. The scale that accumulated on these coupons was a milky-white, crystalline-appearing deposit, known from previous work to be primarily calcium carbonate Each coupon at the start of the test weighed 15-20 g. Use of these coupons quantitatively measures the combined effects of corrosion and scaling, and these data show some interesting effects. It appears from the results of the baseline test that the rate of scaling is greater in Air Stripper No. 1. This result, and the chemical analyses, in particular the change in $\mathrm{pH}$, indicate that the major change in water chemistry occurs in Air Stripper No. 1 and that a further change in No 2 is minimal. Secondly, the Belsperse 161, injected at a rate of $1.5 \mathrm{mg} / \mathrm{L}$, inhibited the scale from forming on both types of stainless steel coupons during the 29 days test. Thirdly, in the baseline test, scale buildup on the Type 316 coupon was less than that on the Type 304 coupon, probably because it is less susceptible to corrosion.

Table 3. Changes in weight of the stainless-steel screen coupons The baseline data is from a test run in June, 1996.

\begin{tabular}{llllll}
$\begin{array}{l}\text { Test } \\
\text { No. }\end{array}$ & $\begin{array}{l}\text { Air } \\
\text { Stripper }\end{array}$ & $\begin{array}{l}\text { Type } \\
\text { of Steel }\end{array}$ & $\begin{array}{l}\text { Weight } \\
\text { Gain } \\
\text { (g) }\end{array}$ & $\begin{array}{l}\text { Duration of } \\
\text { Test } \\
\text { (days) }\end{array}$ & $\begin{array}{l}\text { Scale } \\
\text { Build-up } \\
\text { Rate } \\
\text { (g/day) }\end{array}$ \\
\hline Baseline & 1 & 304 & 101261 & 16 & 0.63 \\
& 2 & 304 & 3.3153 & 7 & 0.56 \\
Baseline & 1 & 316 & 39188 & 16 & 021 \\
& 2 & 316 & 2.1859 & 7 & 0.31 \\
Belsperse 161 & 1 & 304 & -00043 & 29 & 0 \\
& 2 & 304 & -0.0107 & 29 & 0 \\
Belsperse 161 & 1 & 316 & -0.0061 & 29 & 0 \\
& 2 & 316 & -00020 & 29 & 0 \\
\hline
\end{tabular}


Concentration of Phosphate in Effluent Water

Phosphate in treated ground water discharged to the retention basin can stimulate algae blooms by providing algae with a nutrient source Because algae blooms in the basin can deplete the oxygen content of the water and may clog the waterways, a scale treatment that does not increase the phosphate content is desirable. The TFD influent water contains about 007 $\mathrm{mg} / \mathrm{L}$ o-phosphate The JP-7 calcite scale treatment increases the phosphate content an average of $135 \mathrm{mg} / \mathrm{L}$ As shown in Table 4, greater than a 10-fold decrease in o-phosphate occurred when JP-7 was replaced with Belsperse 161 at an injection rate of $1.5 \mathrm{mg} / \mathrm{L}$ The difference between the influent water value of $0.085(2 / 3 / 98)$ and the effluent water with Belsperse 161 of $0.10 \mathrm{mg} / \mathrm{L}$ $(2 / 17 / 98)$ is not significant and close to the limit of detection using EPA 3652 (LOD is $0050 \mathrm{mg} / \mathrm{L}$ ).

Table 4. Orthophosphate concentration of TFD water.

\begin{tabular}{|c|c|c|c|}
\hline \multirow[b]{2}{*}{ Date Sampled } & \multicolumn{3}{|c|}{ o-phosphate $(\mathrm{mg} / \mathrm{L}$ ) } \\
\hline & Influent water & $\begin{array}{l}\text { Effluent water } \\
\text { with IP-7 }\end{array}$ & $\begin{array}{l}\text { Effluent water } \\
\text { with Belsperse } 161\end{array}$ \\
\hline $6 / 4 / 96$ & & 1.6 & \\
\hline $12 / 11 / 96$ & & 2.4 & \\
\hline $3 / 5 / 97$ & & 082 & \\
\hline 4/9/97 & 0.062 & & \\
\hline 6/11/97 & & 0.58 & \\
\hline $2 / 3 / 98$ & 0.085 & & \\
\hline $2 / 17 / 98$ & & & 0.10 \\
\hline
\end{tabular}

$\begin{array}{llll}\text { Average value } & 0074 & 1.35 & 0.10\end{array}$

\section{LPR Measurements}

The linear polarization resistance (LPR) technique was not as sensitive as expected in detecting differences in scaling rates However, the LPR measurements at probe \#1, before dispersant addition, were similar to the readings at \#2, a location after the dispersant addition (Fig. 3) This indicates that despite the change in water chemistry, the calcite was kept in suspension enough to flow through the system and not settle onto the LPR probes. As seen in the figure, the mild steel coupons rapidly corrode during the initial $48 \mathrm{~h}$ because the calcite is accumulating on the coupons and decreasing the corrosion rate. Probe \#1 was in water with an LSI of -0.09 (slightly corrosive) Probe \#2 was in water with an LSI of 1.23 (scaling) but the scaling is 


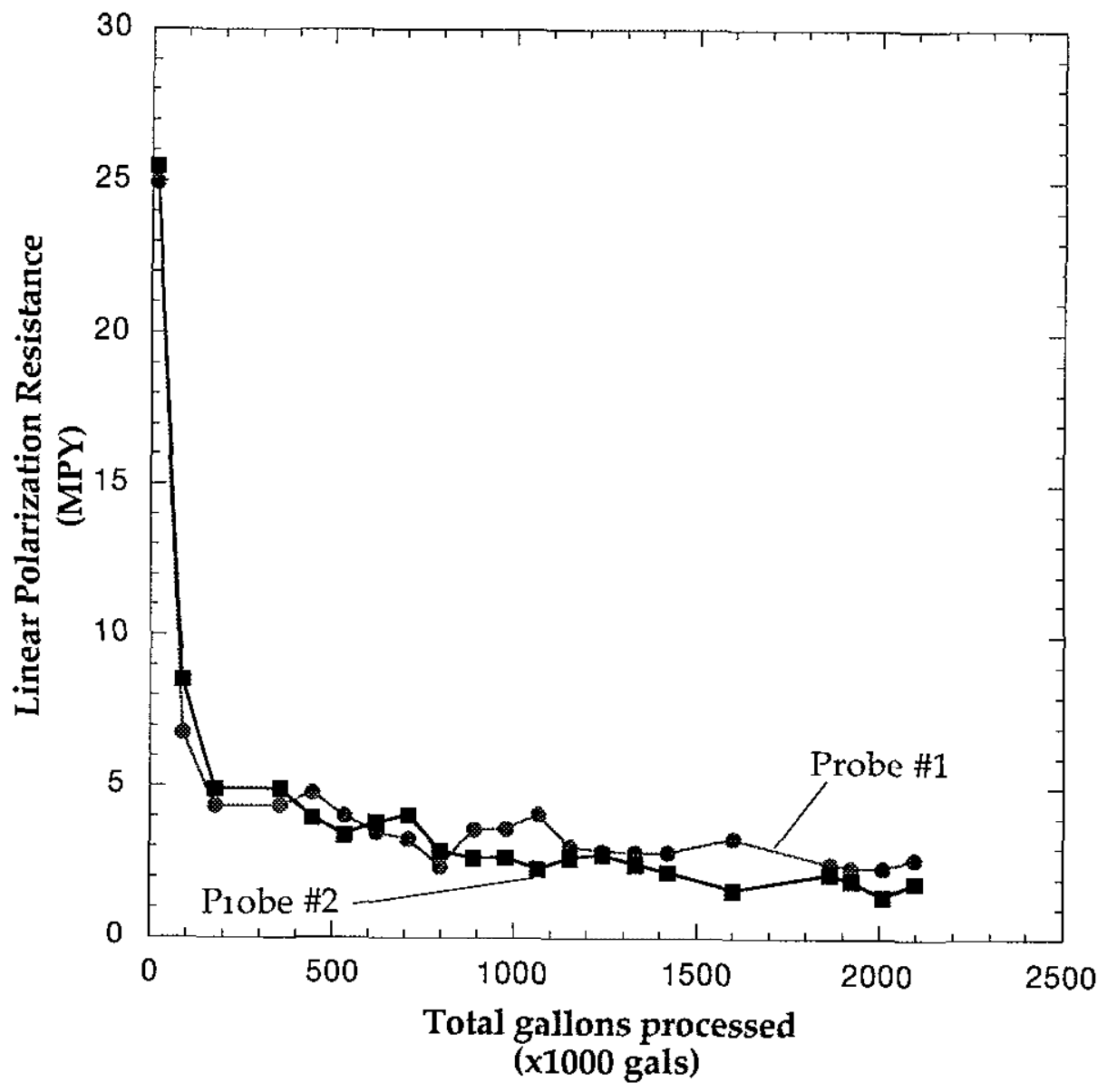

Figure 3 LPR measurements at TFD with a chemical dispersant. Probe \#1 was located upstream of the chemical additive injection site and Probe \#2 was located inbetween the two air-strippers. 
potentially counteracted by the dispersant The water at probe \#2 thus had a corrosion rate similar to that at Probe \#1 The Probe \#2 coupons had slightly lower corrosion rates, indicating that the water is slightly more scaling than the water measured at Probe \#1. Even though the differences are clear, the LPR techniques does not show the effects of scaling dramatically.

\section{Conclusions}

\section{Comparison of Chemical Antiscalant Treatments}

Several potential chemical treatments can be compared with respect to cost One such additive is hydrochloric acid. Due to the large buffering capacity of the ground water, a large volume of concentrated hydrochloric acid must be used to return the $\mathrm{pH}$ to the original value. To achieve a Langelier Saturation Index of 0 in this water would require $100 \mathrm{mg} / \mathrm{L}$ of hydrochloric acid. If $35 \mathrm{gpm}$ is processed, then about $43 \mathrm{lb} / \mathrm{d}$ of acid would be required (based on the equations from Stumm and Morgan's Aquatic Chemistry) In addition to the operator safety concerns, hydrochloric acid would only work if the aeration trays, piping, and so on are highly corrosion resistant

Carbon dioxide is another candidate antiscalant additive Carbon dioxide could be injected directly into the air used for the volatile organic carbon stripping Carbon dioxide would be injected at a rate sufficient to keep the effluent water $\mathrm{pH}$ from rising. This approach was tested with a small pilot facility operated with a side stream at TFD (Krauter et al, 1997). The use of carbon dioxide also raises corrosion concerns, although they would not be as great as with hydrochloric acid

A more benign chemical treatment is the use of polymeric additives This class of chemical treatments has several advantages over other antiscalants. (1) these antiscalants are considered environmentally friendly based on toxicology studies, (2) polymeric additives do not have the hazardous handling qualities of mineral acid antiscalants and (3) these antiscalants can also be used at low dose levels compared to the dose levels of phosphate-based scale inhibitors. This material added to ground water at a dosage of $1.5 \mathrm{mg} / \mathrm{L}$ did not add metals to the effluent nor did it adversely effect the water for fish inhabitation.

In Table 5, scale treatment cost estimates are compared. The crystal modifiers, such as the Belsperse 161 phosphinocarboxylic polymers, require a low dosage for antiscale treatment, thus are presumably most cost effective Carbon dioxide on-site storage would require a 14 ton tank which cost $\$ 316$ per month, this more than doubles the cost of treatment 
Table 5. Cost Estimates for additives based on \$ per million gallons of treated LLNL Water

Antiscalant Cost

Treatment (Dollars)

Carbon Dioxide $105^{\mathrm{a}}$

Hydrochloric acid $\quad 101$

Phosphate additive $\quad 72$

Phosphinocarboxylic polymer $\quad 31$

${ }^{a}$ not including tank rental

In conclusion, the phosphinocarboxylic acid, as evaluated in this investigation, was useful for scale control at Treatment Facility D

\section{References}

Krauter P.W., J E Harrar and S P Orloff (1997) Effect of $\mathrm{CO}_{2}$-Air Mixtures on the $\mathrm{pH}$ of Air-Stripped Water at Treatment Facility D UCRL-ID-129050.

Mansfeld F (1976) "The Polarization Resistance Technique for Measuring Corrosion Currents," in Advances in Corrosion Science \& Technology, M. G Fontana and R W. Staehle, Eds, Plenum Press, New York, 1976, Vol 6, Chapter 3.

Stumm W. and J. J. Morgan (1996) Aquatic chemistry. chemical equilibria and rates in natural waters 3rd ed, Wiley Interscience, New York.

Tchobanoglous G. and E. D Schroeder (1987) Water Quality Characteristics, Modeling, Modification., Addison-Wesley, Menlo Park, CA. 


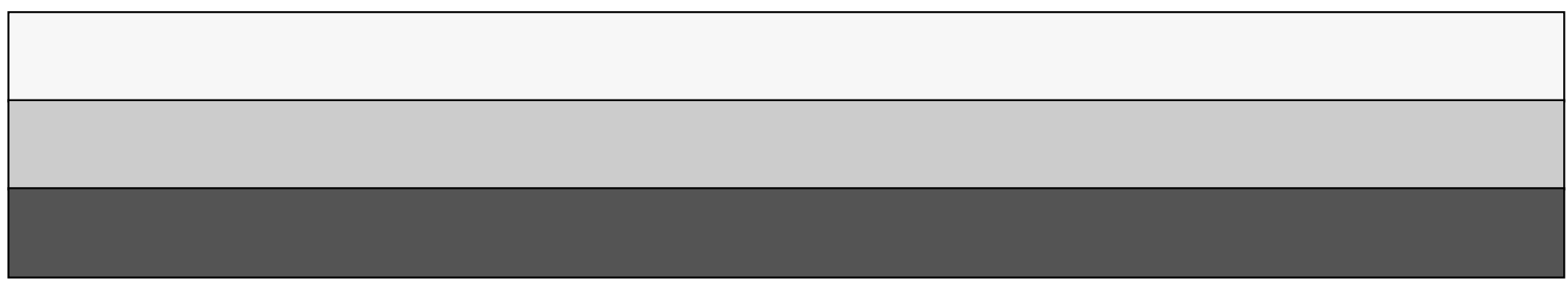

